\title{
Kinga Jęczmińska*
}

\section{The Unsaid in Samuel Beckett's The Unnamable The Subject and the Mind}

DOI: http://dx.doi.org/10.12775/LC.2020.033

\begin{abstract}
The article analyses the concept of the mind in Samuel Beckett's The Unnamable to argue that the subject of the monologue may be interpreted either as a spirit describable in terms of Cartesian substance dualism or as a purely linguistic manifestation of consciousness that is fragmented and not fully articulated. The narrator appears as a "diminished mind" or a "virtually disembodied" voice (Kennedy 1989: 139) that obsessively and desperately searches for the lost or fragmented core of the self (Kennedy 1989: 140; cf. McDonald 2007: 103). The voice might come from a soul suspended in a limbo or in a Geulingian hell where the devil makes its inhabitants uncertain of anything and encourages them to continue their searches for meaning and sense despite the pointlessness of the endeavour (Uhlmann 2006: 104-105). However, the voice may also result from an undisciplined process of writing that produces an uncertain and underdeveloped identity of the narrator. The two interpretations may be treated as compatible with each other.
\end{abstract}

Keywords: Samuel Beckett, The Unnamable, subject, mind

* PhD in Philosophy (University of Warsaw, 2018), PhD in Medicine (Jagiellonian University, 2019), PhD student in English Literature (Jagiellonian University). Interests include contemporary English literature, analytic philosophy of mind, neuroscience and history of psychiatry.

E-mail: kinga.jeczminska@gmail.com| ORCID: 0000-0002-6975-9002. 


\title{
Niewypowiedziane w Nienazywalnym Samuela Becketta Podmiot i umysł
}

\begin{abstract}
Streszczenie: Artykuł analizuje pojęcie umysłu w Nienazywalnym Samuela Becketta w celu wykazania, że podmiot monologu może być rozumiany w dwojaki sposób: jako duch opisywalny z perspektywy kartezjańskiego dualizmu substancjalnego lub jako czysto językowa manifestacja świadomości, która jest fragmentaryczna i nie w pełni wyartykułowana. Narrator ukazuje się jako niepełny umysł lub w zasadzie bezcielesny głos (Kennedy 1989: 139), który obsesyjnie i desperacko szuka utraconego lub fragmentarycznego rdzenia jaźni (Kennedy 1989: 140; cf. McDonald 2007: 103). Głos może należeć do duszy zawieszonej w otchłani lub piekle według koncepcji Geulincxa, w którym diabeł pozbawia jego mieszkańców pewności czegokolwiek i zachęca ich do dalszego szukania sensu i znaczenia pomimo beznadziejności tych wysiłków (Uhlmann 2006: 104-105). Głos może też jednak wynikać z nieuporządkowanego procesu pisania, który prowadzi do niepewnej i nie w pełni rozwiniętej tożsamości narratora. Obie interpretacje można traktować jako ze sobą kompatybilne.
\end{abstract}

Słowa kluczowe: Samuel Beckett, The Unnamable, podmiot, umysł

\section{Introduction}

he Unnamable (published in French in 1953 and in English in 1958) constitutes the last part of Beckett's Trilogy, preceded by Molloy and Malone Dies. It was written in the years 1947-1949, when Beckett was diagnosed with a tumour in his cheek. Although the tumour was benign, at that time Beckett feared that it could be cancerous, which accelerated his work on writing. The fear of imminent death made him produce one of his best works in a very short time (Calder 1992 in: Acheson 1994: 103). The Unnamable has a form of "an incoherent monologue" (Friedman 2018: 191), in which there are visible traces of two sources of influence for Beckett. The first is Dante Alighieri's Divine Comedy, which Beckett studied for his Italian lessons with a private tutor Bianca Esposito during his time at Trinity College Dublin (Knowlson 2014: chapt. 3, sect. II). The second is René Descartes and in particular the philosophy of one of late Cartesians - Arnold Geulincx's, which was extensively examined by Beckett during his École Normale days and later after his return to Dublin (Kennedy 1989: 140; Knowlson 2014: chapt. 9, sect. V; Uhlmann 2006: 70, 78, 104). The article analyses how The Unnamable approaches the idea of the subject and the mind. The thesis of the article is that the subject in Samuel Beckett's The Unnamable can be interpreted in a two-fold manner: as a spirit describable in terms of substance dualism or as a purely linguistic manifestation of consciousness that is fragmented and not fully articulated. It will be argued that the two interpretations are compatible with each other. 


\section{The self as possibly a disembodied spirit}

It may be argued that The Unnamable presents a subject that significantly differs from fully developed human beings. Although the exact nature of the narrator in The Unnamable is uncertain, he has been described by some literary critics as a "diminished mind" or a "virtually disembodied” voice (Kennedy 1989: 139; Friedman 2018: 191). The only source of information about the narrator are his words which form an incongruent monologue. Consequently, serious doubts arise as to the character of his mind and the status of his identity. On the most basic level, the presentation of the narrator's mind in The Unnamable could be compatible with purely phenomenological treatment of the mind. In the phenomenological approach, there is concentration on experiences from the first-person point of view rather than any objective reality (Gallagher 2012: 7-8). The mind could be understood as a basis for various impressions, which does not have to have any contact with a physical body or any physical external world. Some passages of the last part of The Trilogy could be read in a way consistent with an assumption that there are only impressions and there is no certainty about the existence or the nature of the body. The mind can make inferences on the basis of impressions received, from which it tries to figure out possible facts:

I know I am seated, my hands on my knees, because of the pressure against my rump, against the soles of my feet, against the palms of my hands, against my knees. Against my palms the pressure is of my knees, against my knees of my palms, but what is it that presses against my rump, against the soles of my feet? I don't know. My spine is not supported. (Beckett 1965: 304)

The passage may also evoke the idea of Cartesian scepticism. The mind conceives an idea that the subject is in a sitting position, but this knowledge is based merely on impressions related to the feelings of pressure coming to the mind. The sole existence of the mind is sufficient for the existence of the impressions or projections, which do not need to come from a physical body. Even if the subject had some body, it would still not be sure if there were any external objects which would produce the feeling of pressure. In the Cartesian framework, such impressions could be generated by an evil spirit, so they could be fallacious. They might merely generate an illusion of being seated. Therefore, although the subject in The Unnamable seems to be endowed with a mind, its exact nature is unsure and its possible relations with any external reality are uncertain and rather conjectural. Nonetheless, in the section that follows I shall undertake the task of reconstructing a possible ontological scenario described in The Unnamable.

\subsection{The soul in afterlife}

The possible Cartesian treatment of the narrator's impressions supports a related reading of the monologue, in which the source of the narration would be the voice of a soul suspended in a limbo resembling Dante's Inferno (Kennedy 1989: 139-140). The identification of the narrator's mind with a soul or a spirit is aligned with the synonymous treatment 
of the terms "mind" and "soul" in Cartesian philosophy (cf. Descartes 2006a: 29, 39, 48; Descartes 2006b: 95; Descartes 1989: 90).

The narrator of The Unnamable may be "a voice from beyond the grave" (Brater 2003: 51), although its exact nature is not determined: it is not clear whether it comes from a human soul or a different spiritual being. The possibility of treating the subject in The Unnamable as a fallen angel or demigod (Kennedy 1989: 142) could be supported by the narrator's declaration: "I am Matthew and I am the angel, I who came before the cross, before the sinning, came into the world, came here" (Beckett 1965: 301). Yet, the sentence is inherently ambiguous: Matthew is juxtaposed with an angel, who might supposedly have come before Christ or even before the creation of the human world.

Characters who are present in this new realm are described by the narrator in a way that suggests that their material forms either have disappeared or have been at least changed or distorted. This is in line with the narrator's doubts if creatures present in this new place could cast shadows: "Malone is there. Of his mortal liveliness little trace remains. [... It was while watching him pass that I wondered if we cast a shadow. Impossible to say" (ibid.: 292). It seems that beings present in this new realm, e.g. Malone or the narrator, who were described in previous parts of The Trilogy as living entities, have now entered a new phase of existence without their previous mortal bodies. Likewise, the narrator describes himself as a person with no clearly defined material form. His body seems to be in a state of decay, fragmented or dislocated, which brings to mind the surreal image of a decomposed corpse:

My state of decay lends colour to this view, perhaps I had left my leg behind in the Pacific, yes, no perhaps about it, I had, somewhere off the coast of Java and its jungles red with rafflesia stinking of carrion, no, that's the Indian Ocean, what a gazeteer I am, no matter, somewhere round there. (Beckett 1965: 317)

Although the narrator seems to be unsure of what really happened to his body, it does not seem to be of any significant concern to him. It might lead to the interpretation that the narrator is now only a ghost who became separated from his material form, which could explain his indifference to the state or location of his body. Although the narrator does not unequivocally reject the idea that he could still be connected with his body, this option seems implausible. The narrator associates the bodiless state with his emotional or sensational insensitivity: "Ah if I were flesh and blood, as they are kind enough to posit, I wouldn't say no, there might be something in their little idea. They say I suffer like true thinking flesh, but I'm sorry, I feel nothing" (ibid.: 353). This fragment could be interpreted as referring to the Cartesian concept of "a thinking thing" understood as the mind (Descartes 2006b: 15). The narrator seems to deny that he could be "a thinking flesh", which might be understood as a rejection of the material substance. The dual composition of a human, which consists of bodily and spiritual substance, is believed in the framework of Cartesian substance dualism to allow for the separation of the two and an independent existence of the soul. Although Descartes was not able to prove that the soul could be immortal and he believed that it was up to God to decide whether the soul could exist after the death of the body (Descartes 2006b: 90-91), it seems that the narrator has become disentangled from his body and can be now identified only with his mind or soul. 
The narrator has reached a state in which nothing about him changes: "Nothing has ever changed since I have been here. But I dare not infer from this that nothing ever will change" (Beckett 1965: 293). The state of changelessness may stem from the fact that his body no longer performs its physiological functions since it is already dead, which might be especially true of his organ responsible for cognitive processes: "Perhaps it is liquefied brain" (ibid.: 293). The invariability in the mental sphere is contrasted with significant changes that took place in the narrator's dead body after his death. His feelings of immutability are in fact interconnected with and possibly determined by physical changes in his dead body. The state of his bodily decay makes it impossible for the narrator to have normal human feelings: “There is nothing saddening here" (Beckett 1965: 293). On the other hand, the narrator might still have at least an illusion of a material form, since he describes himself as sitting: "No, I have always been sitting here, at this selfsame spot, my hands on my knees, gazing before me like a great horn-owl in an aviary" (ibid.: 293). Nonetheless, the reference to a sitting position may be explained by traditional images of ghosts whose outlines still resemble those of their material bodies.

The narrator may also be interpreted as presenting his final form or "full actualization", which he has reached after death. Since all facts about his existence have been already determined and his human life has come to an end, the narrator may safely say: "Then at last I can set about saying what I was, and where, during all this long lost time” (ibid.: 331). It seems that this state of a final actualization has been achieved recently since the narrator is still not accustomed to it: "For this feeling of being entirely enclosed, and yet nothing touching me, is new" (ibid.: 345). The narrator seems to be a spirit that survived the death of his body and can no longer disappear since it is immortal: "Is not this rather the place where one finishes vanishing?" (ibid.: 293). The narrator also alludes to the Christian idea of creating humans out of dust into which they turn again after their death: "I'm like dust, they want to make a man out of dust" (Beckett 1965: 348). The narrator has probably died as a human and all efforts to bring him back to the state before his death are futile. Thus, it is justifiable to assume that the narrator is of a purely spiritual nature, confined to a realm designated for ghosts, souls or other angels, where he has entered some kind of afterlife.

\subsection{Geulingian hell}

The spiritual realm the narrator is located in may have a specific origin in Western philosophy. This interpretation is in line with research by Anthony Uhlmann who presents the narrator as a soul suspended in Geulingian hell (Uhlmann 2006: 104). Arnold Geulincx (1624-1669) was a Flemish philosopher inspired by Cartesian philosophy, whose descriptions of hell in the works Metaphysica Vera, Metaphysics and Ethics remain pertinent to the analysis of Beckett's works (ibid.: 69-72). Although discussed in the context of René Descartes' and Baruch Spinoza's philosophies, Geulincx remains a rather obscure figure in philosophical circles, but has become well-known in Beckettian studies (ibid.: 69). Beckett examined in detail Geulincx's texts in the Library of Trinity College Dublin, which resulted in his Notes to Arnold Geulincx, Ethica, Metaphysica Vera and Questiones Quodlibeticae now stored at Trinity College Dublin (Uhlmann 2006: 70). Beckett also explicitly refers to Geulincx in the first part of The Trilogy - in Molloy: "I who had loved the image of old 
Geulincx, dead young, who left me free, on the black boat of Ulysses, to crawl towards the East, along the deck" (Beckett 1965: 51).

The possibility that the narrator's location is in fact a kind of hell is supported by his references to Satan. The narrator believes in the existence of the devil and is inclined to think that the place he occupies was created by this evil creature:

For I am obliged to assign a beginning to my residence here, if only for the sake of clarity. Hell itself, although eternal, dates from the revolt of Lucifer. It is therefore permissible, in the light of this distant analogy, to think of myself as being here forever, but not as having been here forever (ibid.: 295-296).

The devil starts to occupy the narrator's thoughts and is treated as another possible inhabitant of the place the narrator is located in: "Worm, Worm, it's between the three of us now, and the devil take the hindmost" (ibid.: 339).

The narrator is sometimes unsure about the true nature of the place he is suspended in. He assumes that it could be hell or paradise or the Earth, in "a typically Beckettian movement of self-contradiction" (Astro 1990: 82). In general, the entire monologue in The Unnamable is characterised by hesitations, doubts and the lack of certainty. This is captured by a humorous remark made by the narrator about the constant human struggle to make inferences: "So they build up hypotheses that collapse on top of one another, it's human, a lobster couldn't do it" (Beckett 1965: 372). The narrator's state of uncertainty resembles Cartesian suppositions that our experiences could be merely a dream. The following fragment illustrates the narrator's confusion which permeates all his knowledge and in particular affects his opinion about the place he occupies:

[...] unusual hell when you come to think of it, perhaps it's paradise, perhaps it's the earth, perhaps it's the shores of a lake beneath the earth, you scarcely breathe, but you breathe, it's not certain, you see nothing, hear nothing, you hear the long kiss of dead water and mud, aloft at less than a score of fathoms men come and go, you dream of them, in your long dream there's a place for the waking, you wonder how you know all you know [...] (ibid.: 392).

This lack of certitude, which leads to constant doubting, is a typical feature of the hell described by Geulincx in Metaphysica Vera. The Geulingian hell is "a place where the guidance of God is removed from us and we become completely unknowing, completely at the mercy of our ignorance" (Uhlmann 2006: 103). The narrator in The Unnamable feels an existential void when he is left to his own devices without any divine supervision. If God exists, he does not care about human existence or fate and is indifferent to human chagrin. The narrator feels abandoned by God: "what have I done to God, what have they done to God, what has God done to us, nothing, and we've done nothing to him, you can't do anything to him, he can't do anything to us" (Beckett 1965: 386). The lack of divine control deprives the narrator of any sense of direction or points of reference.

A recurrent motif in The Unnamable is also a constant effort or compulsion to continue what has been begun. This attitude motivates the narrator to unceasingly investigate various strains of thought. Since there is no consensus on the matters investigated, it leads to the internal split of "the persona of the speaker", who often conducts "an internal argument with itself” (Lyons 1983: 104). This stance marks the memorable ending of the monologue, 
which also captures the idea of a language constructing the identity of the narrator (discussed in section 3):

[... ] you must go on, I can't go on, you must go on, I'll go on, you must say words, as long as there are any, until they find me, until they say me, strange pain, strange sin, you must go on, perhaps it's done already, perhaps they have said me already, perhaps they have carried me to the threshold of my story, before the door that opens on my story, that would surprise me, if it opens, it will be I, it will be the silence, where I am, I don't know, I'll never know, in the silence you don't know, you must go on, I can't go on, I'll go on (Beckett 1965: 414).

The incurable endeavour to continue the musings once they have been started may be associated with the features of hell described by Geulincx. Beckett's Notes to Arnold Geulincx, Ethica, Metaphysica Vera and Questiones Quodlibeticae ${ }^{1}$ from 1936 shed light on possible sources of this image of hell. Geulincx in Opera philosophica describes people in hell as those who stubbornly follow a course of action once chosen:

They are, accordingly, led by stupidity, and a certain stubbornness in acting, and by the diabolical instigation to persist with something once it has been started (for this is at the instigation of the Devil $[\ldots]^{2}$ (in: Uhlmann 2006: 105)

The only reason for those people to continue certain actions is the fact that they have begun them. This mindset is influenced by the devil, who makes people abandon their reasonable assessment of the situation:

we learn from the Inspection of Ourselves that we also are subject to sin, in fact subject to the Devil; for he is the instigator who continually inculcates into us this creed: Continue, because you have begun... since something should not be continued because you have begun it but because Reason dictates it. ${ }^{3}$ (in: Uhlmann 2006: 105)

The narrator's ceaseless questioning and searching may stem from his immersion in a Geulingian hell where all subjects are led on by the devil and left in a state of utter uncertainty.

\section{Linguistic manifestations of the disintegrated and disunified self}

The monologue in The Unnamable has been described by some scholars as an obsessive and "desperate search for the lost" or fragmented "core of the self" (Kennedy 1989: 140;

\footnotetext{
1 Beckett, Samuel 1936. Notes to Arnold Geulincx, Ethica, Metaphysica Vera and Questiones Quodlibeticae, TCD MS 10971/6, Manuscripts Department, Trinity College Library Dublin, Republic of Ireland; typescript, page 24 (in: Uhlmann 2006: 105).

2 Beckett quotes this extract from Opera philosophica by Geulinx in his Notes on page 24.

3 ibid.
} 
cf. McDonald 2007: 103). It may be stated that the narrator in The Unnamable lacks an integrated self (McDonald 2007: 108) since it does not manifest "a unity in thought, emotion, and action", which in cognitive science is a prerequisite for the integration of the self (Kuhl et al. 2015). The experience of the narrator is also not unified (McDonald 2007: 108) since the unification would require that particular experiences should be subsumed in more complex experiences (Bayne 2010: 26-28). In the monologue, there is merely a linear sequence of constantly shifting ideas which are not connected by a common perspective or interrelated themes. This diagnosis corresponds with Charles Lyons's description of the monologue as "a succession of the discoveries and losses of the self", which produces "the shifting vision of a single consciousness" (Lyons 1983: 24), and with Daniel Katz's reference to "the oscillations in The Unnamable between the impossible identifications and the impossible disavowals of the various narrative instances" (Katz 2009: 150). The uncertainty concerning the identity of the narrator may in fact be one of the indications of the incertitude permeating Geulingian hell. The coexistence of these two possible interpretations conforms with Carla Locatelli's idea that The Unnamable's writing undertaken in chaotic circumstances may indicate "that there is no absolute knowing and no absolute not-knowing" (Locatelli 2010, sect. "The extremity..."). The aporic character of the situation described in the novel is responsible for "the sheer indecidability of interpretation and reading" (ibid.: sect. "The extremity...").

The absence of an integrated self and unified experience has distinct linguistic manifestations in the monologue. First of all, the voice may be treated as the result of undisciplined process of writing. The impression of disorderly writing is produced by the use of simple vocabulary, frequent repetitions, pervasive contradictions and uncertainties, difficulties in expressing oneself, and progressing disappearance of punctuation, which results in a monologue that is constituted by incoherent utterances. Secondly, on a deeper level the unsystematic writing may depict the narrator's uncertain and underdeveloped identity. The features of undisciplined writing contribute to the effect of the linguistic manifestation of fragmented consciousness.

In The Unnamable, there is a noticeable concentration on the language itself rather than its possible external references. This focus may give an impression of "mere automatism", in which "language [...] often seems to speak itself" (Maude 2014: 49). The narrator has a liking for juggling with words to find unusual linguistic connections or associations. This inclination is underlined by the narrator in his expression: "he knows how to stimulate the flagging spirit, stop the rot, with the simple use of this mighty word alone $[\ldots]$ " (Beckett 1965: 376). Consequently, the identity of the narrator consists in being both the source and the receiver of linguistic expressions. There is no external audience that could assess or interpret the narrator's expressions. The use of language itself constitutes the subjectivity of the narrator, which is expressed in his words:

Assume notably henceforward that the thing said and the thing heard have a common source [...]. Situate this source in me, without specifying where exactly, no finicking, anything is preferable to the consciousness of third parties and, more generally speaking, of an outer world. (ibid.: 390) 
At the same time, due to a dexterous use of langue, the subject also describes himself as though he possessed the mind, identifiable as his soul, and the body. This dual constitution may be merely the result of a linguistic attribution of dualistic qualities to the subject, which may not correspond to any actual nature of the subject in reality:

Equate me, without pity or scruple, with him who exists, somehow, no matter how, no finicking, with him whose story this story had the brief ambition to be. Better, ascribe to me a body. Better still, arrogate to me a mind. Speak of a world of my own, sometimes referred to as the inner, without choking. Doubt no more. Seek no more. Take advantage of the brand-new soul and substantiality to abandon, with the only possible abandon, deep down within. And finally, these and other decisions having been taken, carry on cheerfully as before. (ibid.: 390)

The story told by the narrator is likely to be simply the product of language, which may not describe any actual situation or even any theoretically possible, non-contradictory situation. In fact, not only the identity of the narrator but also the reality itself are constructed through the use of language. The language does not function as a tool to describe an external reality, but truly constitutes the reality. In Beckett's monologue, to exist is to be formulated within language:

It is I invented him, him and so many others, and the places where they passed, the places where they stayed, in order to speak, since I had to speak, without speaking of me, I couldn't speak of me, I was never told I had to speak of me, I invented my memories, not knowing what I was doing, not one is of me. (Beckett 1965: 395-396)

This approach to the constitution of the subject separates Beckett from modernist fiction and its preoccupation with epistemological issues related to the investigation or inspection of the objective world. As has been pointed by Brian McHale, Beckett's Trilogy exemplifies the transition from modernist to postmodernist fiction (2004: 12-13). The postmodernist aspect of Beckett's prose stems from the abandonment of the mimetic function of literature (McDonald 2007: 88) or any "remnants of the realistic mode" (Brater 2003: 51). Instead of probing a stable external world, Beckett's postmodernist prose "distrusts the idea that the name comes after the thing at all, claiming instead that language constructs its object" (McDonald 2007: 121). The Unnamable may be interpreted as manifesting a characteristic feature of Beckett's postmodernist fiction, in which "There is no self anterior to the speaking self; language makes the self, it does not simply reflect it" (ibid.).

The narrator resorts to the identification with language, since in him language manifests itself, without reference to any objectively existing entities. This approach may be further developed in the direction of Leslie Hill's interpretation of the monologue as the language speaking itself rather than as a manifestation of the existence of some fictional character (Hill 1997: 922). It may also lend support to Marcin Tereszewski's description of The Unnamable as a text in which "language assumes center stage in a spectacle of self-erasure and aporetic logic” (Tereszewski 2008: 68). This identification with language may be associated with the metaphor that compares the narrator to the tympanum, which is a human bodily part where sounds are registered to be later processed and understood as linguistic constituents. The activity of the tympanum resembles the constant activity of the narrator, during which language expresses various ideas that create his identity: 
[... perhaps that's what I feel, an outside and an inside and me in the middle, perhaps that's what I am, the thing that divides the world in two, on the one side the outside, on the other the inside, that can be as thin as foil, I'm neither one side nor the other, I'm in the middle, I'm the partition, I've two surfaces and no thickness, perhaps that's what I feel, myself vibrating, I'm the tympanum, on the one hand the mind, on the other the world, I don't belong to either [...]. (Beckett 1965: 383)

In the tympanum metaphor, the narrator distances himself both from the external world and any subjective world of the mind. Instead, he presents himself as a solely linguistic construct. As a result, the incongruent linguistic expressions create a representation of consciousness that is fragmented and not fully developed. The consciousness produced in this way may not be possessed by any living organism, but could be an entirely theoretical construct, merely a sketch of what could exist. The disunity or disintegration may also be understood as an effect of the subject's ignorance, uncertainties and constant search for something that cannot be attained. This interpretation complies with the vision of a Geulingian hell where the devil makes its inhabitants uncertain of anything and encourages them to continue their searches for meaning and sense although they are utterly futile.

\section{Conclusions}

To recapitulate, it may be stated that The Unnamable is open to two compatible interpretations. Firstly, the subject presented in the monologue could be understood as a spirit suspended in a limbo or hell, which resembles the hell described by a Cartesian philosopher, Arnold Geulincx. Secondly, the subject could be understood as a merely linguistic conceptualization of a disunified or disintegrated consciousness. However, if the reader attempts to reconstruct a possible scenario behind this incongruous monologue, the linguistic inconsistencies and gaps may be interpreted as an indication of the narrator's uncertainty about possible states of affairs. The lingering narration may be understood as the effect of an eternal fight to continue something that has been begun, despite the pointlessness of the endeavour, which resembles the atmosphere of a Geulingian-like hell.

\section{Bibliography}

Acheson, James 1994. "Book Review: Wandering and Home: Beckett's Metaphysical Narrative by Eyal Amiran; Beckett in Dublin by S. E. Wilmer". Journal of Beckett Studies 3, 2 (Spring 1994): 101-104.

Astro, Alan 1990. Understanding Samuel Beckett. Columbia (SC): University of South Carolina Press. Bayne, Tim 2010. The Unity of Consciousness. New York: Oxford University Press.

Beckett, Samuel 1965. Three Novels by Samuel Beckett: Molloy, Malone Dies, The Unnamable. New York: Grove Press, Inc.

Brater, Enoch 2003. The Essential Samuel Beckett. An Illustrated Biography. London: Thames \& Hudson. 
Descartes, René 1989 [1649]. The Passions of the Soul: an English Translation of Les Passions de l'âme. Translated and annotated by Stephen Voss. Indianapolis (IN) \& Cambridge (MA): Hackett Publishing Company.

— 2006a [1637]. A Discourse on the Method of Correctly Conducting One's Reason and Seeking Truth in the Sciences. Translated by Ian Maclean. Oxford: Oxford University Press.

— 2006b [1641]. Meditations, Objections, and Replies. Translated and edited by Rofer Ariew \& Donald Cress. Indianapolis (IN) \& Cambridge (MA): Hackett Publishing Company.

Friedman, Alan 2018. Surreal Beckett. Samuel Beckett, James Joyce, and Surrealism. New York: Routledge.

Gallagher, Shaun 2012. Phenomenology. New York: Palgrave Macmillan.

Hill, Leslie 1997. “«Up the Republic!»: Beckett, Writing, Politics”. MLN 112, 5 (Comparative Literature Issue, December 1997): 909-928.

Katz, Daniel 2009. "What Remains of Beckett: Evasion and History." In: Ulrika Maude \& Matthew Feldman (eds.). Beckett and Phenomenology. London \& New York: Continuum.

Kennedy, Andrew K. 1989. Samuel Beckett. Cambridge University Press.

Knowlson, James 2014. Damned to Fame. The Life of Samuel Beckett. London: Bloomsbury Publishing.

Kuhl, Julius, Markus Quirin, Sander L. Koole 2015. "Being Someone: The Integrated Self as a Neuropsychological System”. Social and Personality Psychology Compass 9, 3 (March 2015): 115-132 .

Locatelli, Carla 2010. “Dying On: Beckett’s Elemental Ghosts”. Limit(e) Beckett 1 (2010): 27-53, on-line.

Lyons, Charles R. 1983. Samuel Beckett. London \& Basingstoke: The Macmillan Press.

Maude, Ulrika 2014. "Convulsive Aesthetics: Beckett, Chaplin and Charcot." In: S. E. Gontarski (ed.), The Edinburgh Companion to Samuel Beckett and the Arts. Edinburgh: Edinburgh University Press.

McDonald, Ronan 2007. The Cambridge Introduction to Samuel Beckett. Cambridge: Cambridge University Press.

McHale, Brian 2004. Postmodernist Fiction. London \& New York: Routledge.

Tereszewski, Marcin 2008. "Towards the Inexpressible Nothing in Becket's Texts for Nothing". Anglica Wratislaviensia 46: 63-72.

Uhlmann, Anthony 2006. Samuel Beckett and the Philosophical Image. Cambridge: Cambridge University Press. 